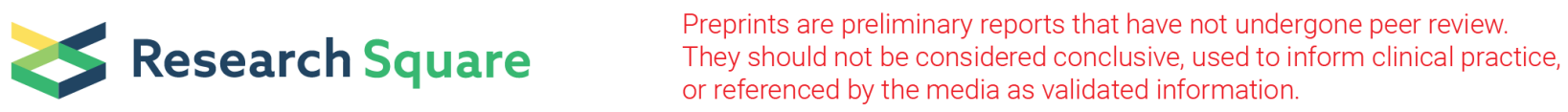

\title{
Systematic Review on Socioeconomic and Environmental Factors of Leptospirosis
}

\author{
Surajo Adamu Wada \\ Universiti Putra Malaysia \\ Vasantha Kumari Neela ( $\sim$ vasantha@upm.edu.my) \\ Universiti Putra Malaysia
}

\begin{abstract}
Research Article
Keywords: Environmental, Incidence, Leptospirosis, Risk factors, Socioeconomic
\end{abstract}

Posted Date: December 15th, 2021

DOI: https://doi.org/10.21203/rs.3.rs-1106071/v1

License: (c) (i) This work is licensed under a Creative Commons Attribution 4.0 International License. Read Full License 


\section{Abstract}

Background: Leptospirosis is a Global emerging zoonotic tropical bacterial disease of the genus Leptospira, with high morbidity and mortality, especially in resource-limited communities. This study is a systematic review on the incidence of socioeconomic and environmental factors of human leptospirosis.

Methods: The research involved published articles from PubMed, Scopus, and Google Scholar electronic databases for nine years. It also encompasses all cases analysed for the risk factors under study reported as numerical percentage incidences. The key terms searched in the database include "leptospirosis, Leptospira, human, patients, socioeconomic, environmental, risk factors, incidence, and prevalence." The search terms from the categories were linked with "OR" and those between categories with "AND." Retrieved articles were saved as comma-separated values (CVS) files and sorted out using the inclusion and exclusion criteria for the study, and then presented in PRISMA plot.

Results: PubMed search revealed 133 that reduced to 14 after eligibility screening. Scopus produced 338 , of which 17 met all the inclusion criteria. Finally, ten publications were qualified for further analysis. Descriptive statistics was used to analysed the association of means of the various factors associated with leptospirosis. Association with rodents had the highest mean incidence of $52.6 \%$ among the environmental factors, whereas farming activity among the socioeconomic factors had the highest mean incidence (44.3\%).

Conclusion: The authority concerned should improve efforts toward health education to farmers regarding personal safety and protective equipment. They should also encourage communities to improve environmental sanitation practices to minimize rodent populations.

\section{Background}

Leptospirosis is one of the world's most common zoonotic diseases caused by pathogenic spiral bacteria of the genus Leptospira. It is a reemerging infectious disease with global veterinary and medical relevance [1]. The genus consists of about 35 species and approximately 300 serovars [2]. The pathogens have many mammalian hosts and are found in high concentrations in renal tubules, subsequently excreted in the environment [3]. Humans are known to be accidental hosts and may not likely transmit the bacteria. The transmission of the infection differs depending on the environmental condition and the socio-economic status that results in vulnerability to the disease [4, 20].

Leptospirosis is a disease that develops mainly through occupational contact. Individuals are at risk of the disease through logging, sewage cleaning, dairy raising, gardening, and agricultural works $[5,6]$. The disease has also been found in individuals who have previously worked as sanitizers, drains and irrigation workers, sewers, waste collectors, road sweepers, miners, farmers, fishers, veterinarians, military personnel, and slaughter workers. People are at risk of contracting the disease through professions that allow contact with dumps, mud, or water bodies [6, 7, 8].

While humans can be infected in various degrees from any of these sources, they play a minor part in the transmission cycle [1]. Association with infected pets, history of flooding and tidal inundation, and vegetations contribute to leptospirosis transmission [28]. In endemic countries, there have been incidents of point-source outbreaks due to leisure and water activities. There have also been adventurous jungle activities, such as hiking, caving, and extreme sports $[6,13]$, which predisposes individuals to the infection. Low income, outdoor jobs, and inadequate health education contribute to an increased risk of leptospirosis infection [16].

Clinical symptoms vary from those that are common to some tropical diseases (malaria, dengue, influenza, and the like), including diarrhoea, nausea, vomiting, body pain, chills, and headache, to life-threatening complications marked by jaundice, renal dysfunction, and haemorrhage, known as Weil's disease. The annual global burden of the disease is approximately 2.9 million, with high mortality of more than 58,900 individuals $[4,6]$.

Leptospiral diagnoses methods in use are polymerase chain reaction, serology, and molecular testing. A single method such as serology alone may not be reliable for antibodies at the acute phase of the disease, but confirmatory tests are recommended and may not always be possible in resource-limited settings. Early diagnosis of the disease is quite challenging since the condition lacks specific symptoms in the early stage and is hardly distinguishable from the acute febrile disorders of the tropics. Preventive measures of incidences related to environmental exposures can be through the enforcement of control measures such as personal protection equipment and environmental management [4] Moreover, since preventive medications are not yet available, the most effective way to control leptospirosis infection is immediate treatment of cases at hand [5]

This study aimed to conduct a systematic review on the incidence of socioeconomic and environmental factors of human leptospirosis through the relevant variables from reliable publications, which determine the specific factors implicated strongly in the transmission of leptospirosis.

\section{Methodology}

Three databases that include PubMed, Scopus, and Google Scholar were searched for the articles between 2011 and 2020 (9 years) as done by Mutalip et al. [6]. The search encompasses all studies on the risk factors of leptospirosis that provided numerical data in the form of percentage incidences. The studies have been retrieved by following the guidelines for Systematic reviews of observational studies in epidemiology provided by Wang et al. [7]. The socioeconomic variables involved include occupation, education, housing, annual income, and recreational activities. The 
environmental variables include history of flooding or presence of water bodies in the vicinity, association with or presence of rodents or associated animals, vegetation, and dump/garbage or sewage.

The key terms "leptospirosis, leptospira, human, patients, socioeconomic, environmental, risk factors, incidence, and prevalence" were searched in the databases. The terms from the categories were linked with "OR", and those between categories with "AND". The articles were searched and analyzed, and the variables that follow the inclusion criteria are qualified for further analysis.

\section{Search formulae}

Google Scholar/PubMed: (Leptospira OR leptospirosis*) AND ("human" OR "patients") AND ("socioeconomic" OR "environmental" OR "risk factors") AND ("prevalence" OR "incidence")

Scopus: ((Leptospira OR leptospirosis*) AND ("human” OR "patients") AND ("socioeconomic" OR "environmental” OR "risk factors") AND ("prevalence" OR "incidence”))

Eligible articles were depicted in PRISMA flow chart as presented by Moher et al. [8] and Tawfik et al. [9].

\section{Inclusion criteria}

Original journal articles that were published in the English language between 2011 and 2020. Full-text articles with abstracts, DOIs, or reliable URL links, and those that have variables numerically presented in percentages. One investigator evaluated the articles and was validated by a second reviewer. All studies that did not meet the inclusion criteria were eliminated. Disagreements between reviewers were resolved by consensus.

\section{Exclusion criteria}

Journals in languages other than English, unpublished, preprints, reviews, and abstracts were also excluded from the study. Journals that have less than four variables among the socioeconomic and environmental factors were excluded from the analysis.

\section{Results}

Among the three search engines used in the study, PubMed database search produced 133 journals, from which 90 were disqualified of irrelevant titles, 19 because of inconsistent abstracts, and ten were with variables that did not fulfil the inclusion criteria; therefore 14 articles were qualified for the study. Scopus produced 338 journals, of which 62 review articles were excluded and 208 discarded having irrelevant titles, 42 removed due to inconsistent abstract, seven papers did not qualify because they did not have the needed variables. Moreover, two non-English articles and three unpublished papers were also removed, leaving 17 eligible for the study. Google Scholar contains no qualified articles.

Figure 1 is a PRISMA presentation that depicts the flow of the systematic review. Scopus had 17 journals, PubMed yielded 14 journals; Google Scholar did not produce any article to analyze, a sum being 31 were eligible, out of which eight duplicates and 13 articles with less than four variables were disqualified, leaving a total of 10 journals for further with the analysis.

Table 1 consist of journals that qualified in the study, 14 were retrieved from PubMed and 17 from Scopus, eight duplicates were removed from the total, and 13 articles with less than four variables disqualified, leaving a total of 10 publications that fulfilled all the inclusion and exclusion criteria for the analysis.

Table 1

Number of articles eligible for further analysis

\begin{tabular}{|ll|}
\hline Search engine & No. of articles \\
\hline Google Scholar & 0 \\
\hline PubMed & 14 \\
\hline Scopus & 17 \\
\hline Disqualified & \\
\hline Duplicates & 8 \\
Variables $\leq 3$ & 13 \\
\hline Total qualified & 10 \\
\hline
\end{tabular}


Table 2 consist of the percentage prevalence of the socioeconomic and environmental factors among the ten qualified articles. All the articles have more than four variables, and they contain numerically scored incidences in percentages. None of the qualified articles had complete representative variables.

Table 2

Percentage incidence of the socioeconomic and environmental factors among qualified articles

\begin{tabular}{|c|c|c|c|c|c|c|c|c|c|c|}
\hline \multirow[t]{2}{*}{$\mathbf{S} / \mathbf{N}$} & \multicolumn{5}{|c|}{ Socio-economic factors } & \multicolumn{4}{|c|}{ Environmental factors } & \multirow[t]{2}{*}{ References } \\
\hline & Occupation & $\begin{array}{l}\text { Educational } \\
\text { background }\end{array}$ & $\begin{array}{l}\text { Monthly } \\
\text { Income } \\
<350 \text { USD }\end{array}$ & $\begin{array}{l}\text { Housing } \\
\text { type }\end{array}$ & $\begin{array}{l}\text { Recreational } \\
\text { activities }\end{array}$ & $\begin{array}{l}\text { Flood } \\
\text { /water } \\
\text { body }\end{array}$ & Vegetation & Rodents & Garbage/dump & \\
\hline 1 & - & $2^{\circ}(70.3 \%)$ & - & $\begin{array}{l}\text { Modern } \\
(11.5 \%)\end{array}$ & $\begin{array}{l}\text { Fishing } \\
(4.2 \%)\end{array}$ & $09.7 \%$ & - & $\begin{array}{l}\text { Other } \\
07.8 \%\end{array}$ & $36.8 \%$ & [9] \\
\hline 2 & $\begin{array}{l}\text { Farming } \\
(54.1 \%)\end{array}$ & - & - & $\begin{array}{l}\text { Modern } \\
(11.0 \%)\end{array}$ & $\begin{array}{l}\text { Fishing } \\
(21.0 \%)\end{array}$ & $35.0 \%$ & - & $55.0 \%$ & - & [10] \\
\hline 3 & $\begin{array}{l}\text { Farming } \\
(41.6 \%)\end{array}$ & - & - & - & $\begin{array}{l}\text { Gardening } \\
(36.0 \%)\end{array}$ & - & - & $65.3 \%$ & $38.9 \%$ & [11] \\
\hline 4 & $\begin{array}{l}\text { Farming } \\
(75.8 \%)\end{array}$ & - & - & - & $\begin{array}{l}\text { Swimming } \\
(87.9 \%)\end{array}$ & $84.9 \%$ & $54.6 \%$ & $78.8 \%$ & - & [12] \\
\hline 5 & $\begin{array}{l}\text { Farming } \\
(3.6 \%)\end{array}$ & $1^{\circ}(46.0 \%)$ & - & - & - & $41.0 \%$ & - & $55.8 \%$ & $32.7 \%$ & $\begin{array}{l}\text { Magalhães } \\
\text { \& Acosta, } \\
\text { [14] }\end{array}$ \\
\hline 6 & - & $2^{\circ}(64.2 \%)$ & $\begin{array}{l}<236.5 \\
(60.8 \%)\end{array}$ & - & $\begin{array}{l}\text { Wadding } \\
(70.0 \%)\end{array}$ & $71.0 \%$ & - & $75.0 \%$ & $81.0 \%$ & [14] \\
\hline 7 & $\begin{array}{l}\text { Farming } \\
(81.0 \%)\end{array}$ & $1^{\circ}(61.0 \%)$ & - & $\begin{array}{l}\text { Local } \\
(48.0 \%)\end{array}$ & $\begin{array}{l}\text { Swimming } \\
(87.3 \%)\end{array}$ & - & - & $65.0 \%$ & - & [15] \\
\hline 8 & $\begin{array}{l}\text { Farming } \\
(32.0 \%)\end{array}$ & $1^{\circ}(63.0 \%)$ & - & $\begin{array}{l}\text { Local } \\
(45.0 \%)\end{array}$ & - & - & - & $33.0 \%$ & $41.0 \%$ & [16] \\
\hline 9 & $\begin{array}{l}\text { Farming } \\
(49.6 \%)\end{array}$ & - & - & $\begin{array}{l}\text { Local } \\
(20.0 \%)\end{array}$ & $\begin{array}{l}\text { Swimming } \\
(66.4 \%)\end{array}$ & $10.6 \%$ & - & $38.4 \%$ & - & $\begin{array}{l}\text { Pages et } \\
\text { al. [17] }\end{array}$ \\
\hline 10 & $\begin{array}{l}\text { Student } \\
(39.0 \%)\end{array}$ & $1^{\circ}(54.0 \%)$ & - & $\begin{array}{l}\text { Local } \\
(57.0 \%)\end{array}$ & $\begin{array}{l}\text { Bathing } \\
(34.0 \%)\end{array}$ & - & - & $70.0 \%$ & - & [18] \\
\hline
\end{tabular}

Table 3 shows descriptive statistics with one-way ANOVA indicating the strength of the factors through the mean of incidences of leptospirosis for each group of the variables. Association with rodents (52.6\%) and farming activities (44.3\%) have the highest mean incidences among the environmental and socioeconomic factors.

Table 3

Mean incidences and standard deviations for the qualified variables.

\begin{tabular}{|lll|}
\hline Socioeconomic variables & Mean incidence & Standard deviation \\
\hline Local housing & $36.2 \%$ & 19.7 \\
\hline Water association/flood & $37.6 \%$ & 28.7 \\
\hline Recreational activities & $41.6 \%$ & 29.8 \\
\hline Farming & $44.3 \%$ & 26.8 \\
\hline Environmental variables & & \\
\hline Garbage /sewage/refuse association & $38.2 \%$ & 25.0 \\
\hline Association with rodents & $52.6 \%$ & 27.2 \\
\hline
\end{tabular}

\section{Discussions}

Leptospirosis is an emerging bacterial zoonosis that has been on the rise around the world. The survival of the bacteria is influenced by the environment and society, which also affects the chance of infection. The severity of the disease in tropical and subtropical areas can be due to 
socioeconomic and environmental factors, such as local Agricultural activities and rodent's diversity [19-21]. Pieces of information related to risk factors for leptospirosis have been ascertained in this study and could help the control measures of the disease.

Socioeconomic and environmental factors have demonstrated a strong trend of being linked to an elevated risk of leptospirosis; the study indicates that farming activities and rodents are the main factors associated with leptospirosis transmission. Association with rodents had the highest mean incidence of $52.6 \%$ among the environmental variables, whereas farming activities constitute $44.3 \%$ among the socioeconomic variables, as shown in Table 3. The limited number of publications that present each risk factor compromises the interpretation of the results. Farming activities and association with rodents pose high risks and are two of the most significant risk factors responsible for spreading leptospirosis in the tropics., as shown by Mwachui et al. [1]; which is in line with the finding of this research.

Agricultural activities are among the socioeconomic factors that contribute to the high prevalence of leptospirosis in the endemic areas [20]. The finding of Guernier et al. [21] indicates that farming activities could increase the burden of human leptospirosis, either individually or in combination with other factors, which shows that the study supports our findings. Moreover, Mathanamohan et al. [22] reported leptospirosis consequences and preventative measures to be occupationally connected to farming. Cross-sectional research conducted by Maze et al. [23] indicated rice field workers to be more predisposed to acute leptospirosis. Binti Daud et al. [14] have found out that cattle farmers are at higher risk of leptospiral infection based on seroprevalence data.

Environmental risk factors of leptospirosis that involves rodents constitute more than half of the cases of leptospirosis [19]. This study implicates rodent exposure as the significant cause of leptospirosis. The concept of exposure varies widely in different parts of the world, with the mean incidence constituting the highest among the environmental factors, according to Daud et al. [24]. Tantia et al. [25] revealed that rodents are known to be the most prevalent source of leptospirosis in humans. Those infected with Leptospira are linked to a high frequency of leptospiral transmission. About 70 percent of patients with leptospirosis-like symptoms had association with rats. Moreover, humans exposed to rats had a 1.7-fold increased incidence of acute leptospirosis.

he rodents' population elevates the risk of exposure to leptospirosis, being known reservoirs for its transmission [26]. The renal carrier status in rodents is one of the factors in the survival and spread of leptospires. The excreter of the rats is one of the sources, with bacteria shed into the environment from the urinary system [27]. Being natural carriers of Leptospira spp., rodents are also found abundantly in plantations; in palm oil farms, there are several different rat types, and the rat population may vary from plot to plot. Favourable environmental condition in the plantations, in addition to a high density of rodents, ensures a conducive environment for the pathogen, thereby contaminating soil and water [12].

A study carried out by Lau et al. [28] reported that the existence of Leptospira antibodies is related to a variety of animal exposures, subjects who confirmed physical interaction with rats or mice had higher infection rates. Boey et al. [29] pointed out that Rodents' control in conjunction with intensified efforts to improve public awareness and knowledge about leptospirosis transmission and prevention. Mwachui et al. [1] also linked rodents to an increased incidence of leptospirosis. It has become a controversial aspect of systematic analysis techniques to summarize results in the heterogeneous between-study effects. Graphs, simulations, the use of the random effect paradigm, and descriptive statistics that measure variability have also been proposed as alternatives as approved by Takkouche et al. [30].

Hence, descriptive statistical analysis is used in this study to compare the means and standard deviation through one-way ANOVA for each of the normally distributed variable groups that have at least four outcomes across the ten qualified articles (Table 3). Forest plot was not applied in the analysis because there were neither control groups nor pre and post-tests involved in the study; case-control studies are not among the searched articles. Random effects have analyzed each group as each study group is conservative and introduces its heterogeneity at $95 \%$ confidence limits, which defines its mean values and standard deviations.

\section{Conclusion}

The most significant reservoirs and sources of Leptospira infection are the rodents. Agricultural activities are the leading contributors to the transfer of leptospirosis from animals to humans. Farmers are at higher risk of contracting leptospirosis as a result of occupational exposures.

Leptospirosis is linked to waste dumping in farms. The authority should make efforts toward health education and promotion strategies to farmers and encourage the community to use personal safety devices such as hand gloves, maintenance of a clean environment to minimize rodent population, and disease transmission. Research initiatives with regards to the control of socioeconomic and environmental factors of human leptospirosis transmission need consideration.

\section{Declarations}

\section{Ethics approval and consent to participate:}

This study does not need ethics approval and consent to participate.

\section{Consent for publication:}


No consent required for publication.

Availability of Data and Material (ADM):

Not applicable. This is a systematic review paper and the references for all data are available in the reference list.

\section{Competing interest:}

Authors have no competing interest.

\section{Funding:}

This study was performed without any financial support.

\section{Authors' contribution:}

All the authors contributed immensely to the successful completion of the manuscript. Dr. Vasantha Kumari Neela has contributed in conceptualization, validation, edition, visualization, supervision and administration. Surajo Adamu contributed for the methodology, formal analysis, investigation, review, edition and writing

\section{Acknowledgement:}

We acknowledge Universiti Putra Malaysia for providing the facilities to carry out the research.

\section{References}

1. Mwachui MA, Crump L, Hartskeerl R, Zinsstag J, Hattendorf J. Environmental and Behavioural Determinants of Leptospirosis Transmission: A Systematic Review. Small PLC, editor. PLoS Negl Trop Dis. 2015 Sep;9(9):e0003843.

2. Vincent AT, Schiettekatte O, Goarant C, Neela VK, Bernet E, Thibeaux R, et al. Revisiting the taxonomy and evolution of pathogenicity of the genus Leptospira through the prism of genomics. PLoS Negl Trop Dis. 2019;13(5):1-25.

3. Garvey P, Connell J, O’Flanagan D, McKeown P. Leptospirosis in Ireland: Annual incidence and exposures associated with infection. Epidemiol Infect. 2014;142(4):847-55.

4. Naing C, Reid SA, Aye SN, Htet NH, Ambu S. Risk factors for human leptospirosis following flooding: A meta-analysis of observational studies. PLoS One. 2019;14(5):1-15.

5. Gasem MH, Hadi U, Alisjahbana B, Tjitra E, Hapsari M, Lestari ES, et al. Leptospirosis in Indonesia: diagnostic challenges associated with atypical clinical manifestations and limited laboratory capacity. BMC Infect Dis. 2020;2020(20):1-11.

6. Dekkers OM, Vandenbroucke JP C, M, Renehan AG, Altman DG EM. Introduction to COSMOS-E: Guidance on conducting systematic reviews and Meta-analyses on etiology of observational studies. PLOS Medicice. 2019;16(2):e1002742.

7. Moher D, Liberati A, Tetzlaff J AD. Preferred reporting items for systematic reviews and meta-analyses: the PRISMA statement. BMJ. 2009;339(b):2535.

8. Tawfik GM, Dila KAS, Mohamed MYF, Tam DNH, Kien ND, Ahmed AM, et al. A step by step guide for conducting a systematic review and metaanalysis with simulation data. Trop Med Health. 2019;47(1):1-9.

9. Atil A, Jeffree MS, Rahim SSSA, Hassan MR, Lukman KA, Ahmed K. Occupational determinants of leptospirosis among urban service workers. Int J Environ Res Public Health. 2020;17(2):1-8.

10. Biscornet L, de Comarmond J, Bibi J, Mavingui P, Dellagi K, Tortosa P, et al. An observational study of human leptospirosis in seychelles. Am J Trop Med Hyg. 2020;103(3):999-1008.

11. Bouscaren N, Coignac CB De, Lastère S, Musso D, Teissier Y, Formont J, et al. Leptospirosis in French Polynesia: 11 years of surveillance data, 2007-2017. New Microbes New Infect. 2019;29(1):100518.

12. Hinjoy S, Kongyu S, Doung-Ngern P, Doungchawee G, Colombe SD, Tsukayama R, et al. Environmental and behavioral risk factors for severe leptospirosis in Thailand. Trop Med Infect Dis. 2019;4(2):1-12.

13. Magalhães VS, Acosta LMW. Leptospirose humana em Porto Alegre, Rio Grande do Sul, de 2007 a 2013: caracterização dos casos confirmados e distribuição espacial. Epidemiol e Serv saude Rev do Sist Unico Saude do Bras. 2019;28(2):e2018192.

14. Binti Daud A, Mohd Fuzi NMH, Wan Mohammad WMZ, Amran F, Ismail N, Arshad MM, et al. Leptospirosis and workplace environmental risk factors among cattle farmers in northeastern Malaysia. Int J Occup Environ Med. 2018;9(2):88-96.

15. Turnier P Le, Mosnier E, Schaub R, Bourhy P, Jolivet A, Cropet C, et al. Epidemiology of human leptospirosis in French Guiana (2007-2014): A retrospective study. Am J Trop Med Hyg. 2018;99(3):590-6. 
16. Dreyfus A, Dyal JW, Pearson R, Kankya C, Kajura C, Alinaitwe L, et al. Leptospira Seroprevalence and Risk Factors in Health Centre Patients in Hoima District, Western Uganda. PLoS Negl Trop Dis. 2016;10(8):1-14.

17. Pagès F, Polycarpe D, Dehecq J, Picardeau M. Human Leptospirosis on Reunion Island: Past and Current Burden. Int J Environ Res Public Health. 2014;11(1):968-82.

18. Reller ME, Wunder EA, Miles JJ, Flom JE, Mayorga O, Woods CW, et al. Unsuspected Leptospirosis Is a Cause of Acute Febrile Illness in Nicaragua. PLoS Negl Trop Dis. 2014;8(7):1-9.

19. Nur Fajriyah, S., Udiyono, A and Dian Saraswati L. Environmental and Risk Factors of Leptospirosis: A Spatial Analysis in Semarang City Silviana. Earth Environ Sci. 2018;55(1):1-10.

20. Zakharova OI, Korennoy FI, lashin I V., Toropova NN, Gogin AE, Kolbasov D V., et al. Ecological and Socio-Economic Determinants of Livestock Animal Leptospirosis in the Russian Arctic. Front Vet Sci. 2021;8(April):1-11.

21. Guernier V, Goarant C, Benschop J, Lau CL. A systematic review of human and animal leptospirosis in the Pacific Islands reveals pathogen and reservoir diversity. Vol. 12, PLoS Neglected Tropical Diseases. 2018. 1-32 p.

22. Mathanamohan J, Kaleel F, Hyderaly H, Imthiyaz I, Unais R, Nisansala T, et al. Farmers' occupational health, perception and practices towards leptospirosis: A cause for concern. Sri Lankan J Infect Dis. 2020;10(1):21.

23. Maze MJ, Cash-Goldwasser S, Rubach MP, Biggs HM, Galloway RL, Sharples KJ, et al. Risk factors for human acute leptospirosis in northern Tanzania. PLoS Negl Trop Dis. 2018;12(6):1-22.

24. Daud A, Fuzi NMHM, Arshad MM, Kamarudin S, Mohammad WMZW, Amran F, et al. Leptospirosis seropositivity and its serovars among cattle in Northeastern Malaysia. Vet World. 2018;11(6):840-4.

25. Nova, TIR. I, Susanna D, Warsito GM. the Presence of Rodents Infected With Leptospira Bacteria in Various Countries and the Leptospirosis Potential in Humans: a Systeaaatic Review. Malaysian J Public Heal Med. 2020;20(2):185-96.

26. Briskin EA, Casanovas-Massana A, Ryff KR, Morales-Estrada S, Hamond C, Perez-Rodriguez NM, et al. Seroprevalence, Risk Factors, and Rodent Reservoirs of Leptospirosis in an Urban Community of Puerto Rico, 2015. J Infect Dis. 2019;220(9):1489-97.

27. Rahayu S, Adi MS, Saraswati LD. Mapping of Leptospirosis Environmental Risk Factors and Determining the Level of Leptospirosis Vulnerable Zone in Demak District Using Remote Sensing Image. E3S Web Conf. 2018;31(2018):1-9.

28. Lau CL, Watson CH, Lowry JH, David MC, Craig SB, Wynwood SJ, et al. Human Leptospirosis Infection in Fiji: An Eco-epidemiological Approach to Identifying Risk Factors and Environmental Drivers for Transmission. PLoS Negl Trop Dis. 2016;10(1):1-25.

29. Boey K, Shiokawa K, Rajeev S. Leptospira infection in rats: A literature review of global prevalence and distribution. PLoS Negl Trop Dis. 2019;13(8):1-24.

30. Takkouche B, Khudyakov P, Costa-Bouzas J, Spiegelman D. Confidence intervals for heterogeneity measures in meta-analysis. Am J Epidemiol. 2013;178(6):993-1004.

\section{Figures}




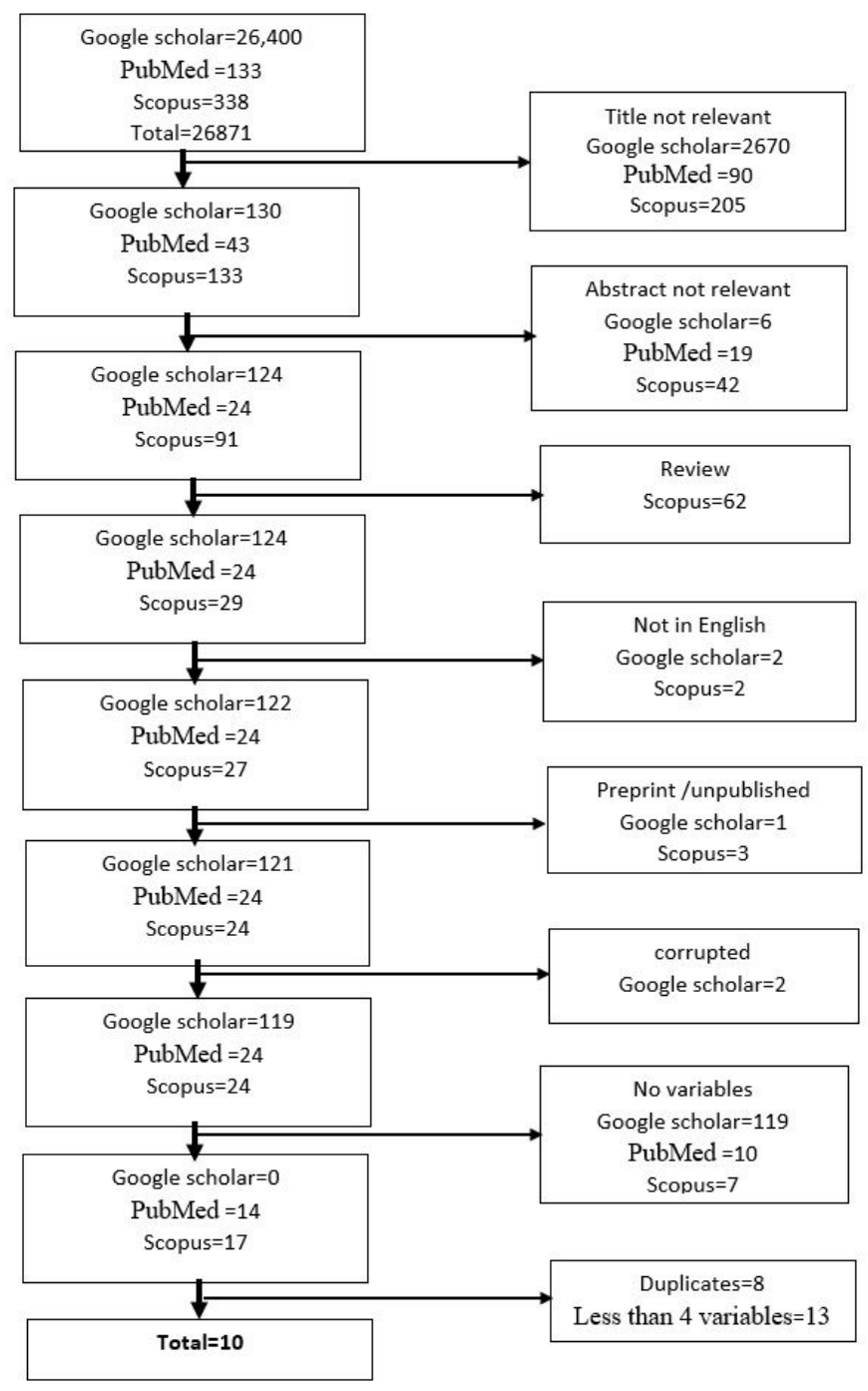

Figure 1

Prisma presentation to summarize the searched articles 